\title{
A liquidez da modernidade na narrativa de Sérgio Sant'Anna: representações do desejo e da violência
}

\author{
The Liquidity of Modernity in the Narrative of Sérgio Sant'Anna: \\ Representations of Desire and Violence \\ La liquidez de la modernidad en la narrativa de Sérgio Sant'Anna: \\ representaciones del deseo y la violencia \\ Márcia Denise da Rocha Collinge* \\ Elielson Figueiredo*
}

\section{Resumo}

O presente trabalho embarca em um voo ambivalente que transporta representações da modernidade líquida - metáfora da fluidez da "existência" contemporânea, desenvolvida pelo sociólogo Zygmunt Bauman. Inseridos em tal cenário líquido, os relacionamentos humanos ocupam o cerne das atenções na produção artística brasileira contemporânea. O propósito deste artigo é destacar os temas suscitados nos meandros das narrativas de tal modernidade, tais como o desejo, o medo e a violência. Para tanto, apresentar-se-á uma interpretação pautada na visão estético-recepcional de Hans Robert Jauß do conto "O embrulho da carne", da obra O voo da madrugada (2003), do escritor brasileiro Sérgio Sant'Anna.

Palavras-chave: modernidade líquida, desejo e violência, “O embrulho da carne”, Sérgio Sant'Anna.

Abstract

The present work embarks on an ambivalent flight that transports representations of liquid modernity, a metaphor of fluidity of contemporary "existence," developed by the sociologist Zygmunt Bauman (1925). In such a liquid scenario, human relationships are at the center of attention in the production of contemporary Brazilian art. The purpose of this paper is to highlight themes raised in the complexities of narratives of liquid modernity, such as desire, fear and violence. To this end, we present an interpretation based on the aesthetic-receptional vision of Hans Robert Jauß in the short story "O embrulho da carne", from the work $O$ voo da madrugada (2003), by the Brazilian writer Sérgio Sant' Anna.

Keywords: liquid modernity, desire and violence, "O embrulho da carne", Sérgio Sant'Anna.

\section{Resumen}

El presente trabajo se embarca en un vuelo ambivalente que conlleva representaciones de la modernidad líquida - metáfora de la fluidez de la "existencia", desarrollada por el sociólogo Zygmunt Bauman (1925). En tal escenario, las relaciones humanas ocupan el centro de atención en la producción artística contemporánea brasileña. El propósito de este artículo es destacar los temas planteados en las complejidades de tales narrativas modernas, como el deseo, el miedo y la violencia. Por lo tanto, presenta una interpretación basada en la visión estética-recepcional de Hans Robert Jauß del cuento O embrulho da carne, de la obra $O$ voo da madrugada (2003), del escritor brasileño Sérgio Sant' Anna.

Palabras-clave: modernidad líquida, deseo y la violencia, “O embrulho da carne”, Sérgio Sant'Anna.

\footnotetext{
* Instituto Federal do Pará (IFPA), Belém, PA, Brasil. (Dorcid.org/0000-0003-0688-5674. E-mail: io.marciadenise@ gmail.com ** Universidade do Estado do Pará (UEPA), Belém, PA, Brasil. (Dorcid.org/0000-0003-3934-4903. E-mail: elielson@uepa.br
} 


\section{Convite ao voo da modernidade na obra de Sérgio Sant'Anna}

No intuito de bem compreender a obra de Sérgio Sant'Anna nos quadros da literatura brasileira contemporânea, emerge a pertinência de travar uma discussão acerca de uma de suas obras mais representativas. Trata-se do conjunto de contos $O$ voo da madrugada (2003). Nessa coletânea, podemos visualizar o desenvolvimento de temas caros à contemporaneidade que se integram à subjetividade das protagonistas de modo a compor quadros de raro refinamento narrativo e sutileza analítica.

Entre as narrativas que compõem o volume, discutir-se-á "O embrulho da carne" a fim de reconhecer as representações, sobretudo, da violência e do desejo que perpassam a trama e se fazem ver principalmente no âmbito das relações interpessoais travadas entre as personagens. Para tratar dessas relações, elegeu-se o conceito de liquidez formulado por Zygmunt Bauman ao longo de sua obra - amplamente traduzida para o português e publicada no Brasil particularmente entre os anos de 2001 e 2006. Ademais, dedicar-se-á especial atenção à leitura de "O embrulho da carne", em perspectiva estético-recepcional, a partir das teses defendidas por Hans Robert Jauß.

\section{A liquidez da Modernidade}

Em um de seus mais conhecidos trabalhos - Modernidade líquida $(2001)^{1}$ _, Bauman expõe com argúcia seu conceito de liquidez na tentativa de fazer um inventário sociológico do cotidiano das sociedades ocidentais no curso das duas últimas décadas do século XX. É neste período que o sociólogo polonês delimita a transição do que chama de Modernidade pesada para uma Modernidade leve e líquida, o que conduz ao entendimento de que não estamos diante de uma Modernidade superada por um novo conjunto ideológico ou projeto de sociedade. Para Bauman, estamos vivendo um novo estágio da Modernidade, este marcado pela instantaneidade e pelo fragmentarismo.

A Modernidade líquida é marcada pela mobilidade e pela velocidade. Os fluxos de bens em oferta correm líquidos para se moldarem muito convenientemente às exigências e conveniências do consumidor, embora a maior exigência seja a possibilidade de consumir a esmo e com garantias de satisfação imediata e transitória. Se a Modernidade sólida fincou identidades coletivas ao redor de territórios e classes sociais gerando sentimentos de pertencimento e comunitarismo, a liquidez pulverizou os projetos coletivos que antes visavam ao bem comum e ergueu a soberania do indivíduo sobre as causas sociais. Liberto dos grandes ideais que regulavam identidades anteriores a si, o homem líquido entregou-se ao prazer de relativizar as certezas impostas pelas tradições às quais se vinculava e, uma vez livre, o indivíduo tratou de reescrever-se continuamente, seguindo vorazmente uma urgência de aderir a tudo que lhe satisfaz o gozo instantâneo sem critérios éticos, ideológicos ou mesmo culturais chancelados por instituições superiores como a história, deus ou a classe social.

A liquidez, portanto, implica uma experiência de tempo. Quando a tecnologia permitiu ao homem o deslocamento por grandes espaços num tempo cada vez menor, as formas de percepção do mundo tornaram-se impregnadas da experiência da instantaneidade. Certo de que pode escolher quem quer ser e posto diante de inúmeras possibilidades, o homem contemporâneo dispõe de mais meios que fins a atingir. Essa nova circunstância, se comparada às sólidas identidades sociais antigas, produz uma ambivalência que deixa suspenso o indivíduo entre duas certezas: alcançar e descartar imediatamente. Vale dizer que a possibilidade de ser tantos implica uma esmagadora incapacidade de ser pleno em definitivo. Para Bauman, essa redução do indivíduo a si imprime ao cotidiano das pessoas uma inevitável experiência de fracasso se considerarmos que, ao lado da liberdade levada ao extremo, vivencia-se a incerteza quanto a saber quem se é, a precariedade dos vínculos humanos e a insegurança de quem caminha sem propósito. Não há ideias, não há convicções de princípio, não há sacrifícios que rendam recompensas nem culpas que necessitem perdão. Nas palavras do próprio autor:

\footnotetext{
${ }^{1}$ Todas as datas referentes a textos de Zygmunt Bauman correspondem às primeiras edições no Brasil.
} 
Diferentemente da sociedade moderna anterior, que chamo de "Modernidade sólida", que também tratava sempre de desmontar a realidade herdada, a de agora não o faz com uma perspectiva de longa duração, com a intenção de torná-la melhor e novamente sólida. Tudo está agora sendo permanentemente desmontado, mas sem perspectiva de alguma permanência. Tudo é temporário. É por isso que sugeri a metáfora da "liquidez" para caracterizar o estado da sociedade moderna: como os líquidos, ela caracteriza-se pela incapacidade de manter a forma. Nossas instituições, quadros de referência, estilos de vida, crenças e convicções mudam antes que tenham tempo de se solidificar em costumes, hábitos e verdades (Pallares-Burke, 2004, p. 321-322).

Para apontar o agente da passagem de uma Modernidade sólida para o estágio atual da Modernidade, podemos dizer que o capital agencia e controla a liberdade para desmotivar, demover os indivíduos de aspirações revolucionárias ou alternativas para a ordem social. Quando o acesso ao capital e aos bens se tornou uma possibilidade, todas as aspirações coletivas caíram no fosso do desinteresse e o capital pôde, assim, ampliar e conduzir à fantasia e ao desejo individuais. Dessa forma, todo desejo é estreitamente condicionado ao que se oferece para ser consumido, mas nada que agora nos seja dado a consumir pode ser tão duradouro a ponto de nos comprometer a extensão do desejo. Antes que nos desencantemos e acordemos cheios de perguntas sobre a falsa liberdade de que gozamos, novos anseios são acesos em nós, obrigando-nos à lei do instante. Refletindo acerca dessa ilusão de liberdade projetada pelo capital, Bauman menciona a individualização ou solução biográfica como estratégia para que a dimensão pública e coletiva da vida seja solapada por níveis elevados de crença e decepção voltados para o próprio indivíduo, mistificando-o e tornando-o autocontemplativo, obsessivamente perseguido pelo temor do fracasso e pela necessidade de felicidade imediata:

Que homens e mulheres não tenham nada a que culpar por suas frustrações e problemas, não precisa agora significar [...] que possam se proteger contra a frustração utilizando suas próprias estratégias [...]. E, no entanto, se ficam doentes, supõe-se que é porque não foram suficientemente decididos e industriosos para seguir seus tratamentos; se ficam desempregados foi porque não aprenderam a passar por uma entrevista, ou porque não se esforçaram o suficiente para encontrar trabalho [...]. Isto é, em todo caso, o que lhes é dito hoje, e aquilo em que passaram a acreditar, de modo que agora se comportam como se essa fosse a verdade (Bauman, 2001, p. 43).

Aplicada às relações interpessoais, a liquidez revela formas de relacionamento cada vez mais voláteis moldadas pela ambivalente necessidade de estabelecer laços afetivos sem compromisso de permanência. Em Amor líquido (2004), Bauman mostra que os indivíduos resistem ao vínculo duradouro porque se sentem inseguros para fazer investimentos a longo prazo. A maioria das pessoas não quer assinar apólices em branco comprometendo-se em fazer do presente uma experiência eterna. Nas relações interpessoais, como nas operações de mercado, busca-se satisfação garantida e a certeza de que, em caso de problemas, será possível substituir o bem por outro, novo, melhor, mais bonito, mais veloz.

Servindo à lógica da velocidade e do consumismo, o amor líquido é vivido como máxima experiência da liberdade individual e entendido como possibilidade ou poder de escolha orientado pelo imperativo do desejo. Ao invés de mediar conflitos e tensões dentro de um compromisso duradouro, os envolvidos na experiência líquida preferem o imediatismo dos encontros casuais, dessa maneira mantendo sempre possíveis novas e simultâneas experiências de satisfação sem obrigação. Tantas possibilidades e oferta abundante de meios para o consumo levam os consumidores desse amor informal (sem forma ou contorno rígidos) a um desengajamento, ou seja, a uma diversidade de parceiros e relacionamentos breves, capaz de impressionar em número e velocidade. Estabilidade e duração são entendidas como fardos, o incessante exercício amoroso é uma condição de inclusão e aceitação nos ambientes sociais e pela qual se pode reconhecer a habilidade e o êxito do consumidor.

Preocupados mais com o descarte do que há pouco era interessante, os amantes são seduzidos pela ideia de trocar ou alternar experiências amorosas sem traumas ou rupturas drásticas. É diante dessa necessidade que Bauman utiliza o conceito de "redes" para explicar a política 
cotidiana dos relacionamentos. Embora as pessoas temam a solidão e o fracasso, o que as impede de parar a busca por novas conexões, temem mais ainda a obrigatoriedade de um vínculo que as prive de outras promessas de satisfação, de novos encontros instantâneos. Neste quadro de atitudes, desconectar-se sem burocracias e constrangimentos é mais valioso que conectar-se.

Contudo, a sedutora promessa de prazer sem esforços escamoteia os vazios deixados pela sensação de estar sempre à deriva. Para Bauman, o sexo - entendido como prazer com fim em si mesmo e desvinculado de funções sociais de paternidade/maternidade - tem sido uma experiência de solidão a dois, "porque a união alcançada no breve instante do clímax orgástico 'deixa os estranhos tão distantes um do outro como estavam antes', de modo que 'eles sentem seu estranhamento de maneira ainda mais acentuada'" (2004, p. 63). Cada vez mais naturalizado e obediente ao corpo, portanto, livre dos meandros da civilidade e da moral religiosa, o sexo aumentou "enormemente sua capacidade de gerar frustração e de exacerbar a própria sensação de estrangulamento que se esperava que curasse" (2004, p. 63). Isto significa dizer que quando o sexo "pouco evoca senão uma prazerosa sensação física, ele não está liberado de fardos supérfluos, avulsos, inúteis, incômodos e restritivos. Está, ao contrário, sobrecarregado, inundado de expectativas que superam sua capacidade de realização" (Bauman, 2004, p. 64-65).

Assim, entendidas as linhas gerais da Modernidade líquida e suas nuances sobre as relações interpessoais, passamos a nos deter sobre a ficção de Sérgio Sant'Anna e particularmente sobre o conto "O embrulho da carne", na perspectiva de entendê-lo como representação das ambivalências da vida líquida, esta marcada por experiências de violência e desejo.

\section{A liquidez da Modernidade na obra de Sérgio Sant'Anna}

Sérgio Sant'Anna (1941) - autor de romances, novelas, poesias, contos e peças de teatro, premiado e traduzido para diversas línguas, como o italiano, o alemão e o espanhol curiosamente considerava-se apenas contista, já que afirmara sua predileção pela narrativa breve, a qual the permitia fazer as experimentações na linguagem que buscava em sua literatura, tendo marcado o cenário artístico-literário brasileiro contemporâneo com sua escrita em constante reinvenção, dada a sua "obstinação por não se repetir" (Sant'Anna, 2012). Desse modo, não raros são os críticos que convergem para o pensamento da estudiosa da literatura contemporânea Regina Dalcastagnè (2003, p. 209): “Sant'Anna é autor essencial para quem quer pensar a literatura no Brasil hoje".

Um de seus textos mais premiadas, $O$ voo da madrugada (2003) - vencedor do prêmio Jabuti (2004), laureado como melhor publicação do gênero pela Associação Paulista dos Críticos de Arte (APCA), bem como pelo internacional Prêmio Telecom de Literatura Brasileira -, apresenta pontos de convergência com a temática da Modernidade líquida. Acerca da estrutura, O voo da madrugada é composto de 15 contos e uma novela, sendo dividido em três partes: a primeira parte compõe-se de 12 contos que se bifurcam em múltiplas leituras, a partir de tônicas reveladoras do volátil cenário da Modernidade líquida - violência, sexo, melancolia, crueldade e solidão; a segunda centra-se numa narrativa mais longa, seguindo o gênero novela; e por fim, a terceira parte apresenta três textos curtos sobre o olhar.

Quanto à primeira parte, já no primeiro e homônimo conto, acompanhamos um homem solitário na viagem em um avião que transporta cadáveres. No voo, surge uma mulher misteriosa com a qual são trocados olhares e carícias, na qual ele entrevê uma possibilidade de ser amado. Adormece abraçado à mulher e, ao chegar ao seu destino, percebe que a mulher desembarcou sem deixar vestígios. A fragilidade dos relacionamentos humanos fica evidente pelo signo da incerteza que permeia o conto. A partir do primeiro conto, os próximos se desenrolam a partir de uma voz narradora que é sempre reinventada. Passam-se situações-limites, circunstâncias nefandas em que a cidade, em estado metafórico-metonímico, pode representar qualquer espaço urbano da Modernidade líquida em que vigoram situações de prostituição, suicídio, violência, incesto e solidão em meio ao desejo de estar com o outro. A segunda parte da obra centra-se na novela "O Gorila", um homem que assume o pseudônimo do título para passar trotes telefônicos de teor obsceno a mulheres desconhecidas. Na tentativa de mascarar sua insegurança é que o estopim de 
sua solidão é acionado e ele acaba por dar cabo à sua vida. Por fim, a terceira parte do livro reúne "Três textos do olhar" - qualificativo do próprio autor, que se refere às variações de obras pictóricas com o objetivo de ressaltar a perspectiva daquele que vê.

Apesar do desmembramento em três partes empreendido pelo próprio autor, Regina Dalcastagnè vê uma harmonia entre estas com base na temática da solidão:

Talvez mais do que a morte, é a solidão que dá unidade ao livro - e, ligada a ela, um terrível sentimento de fracasso, que impregna tudo. A solidão pode ser, ela mesma, um sintoma do malogro na ambição primária de todo ser humano: estar com o outro (Dalcastagnè, 2003, p. 210).

Ao adentrarmos nos meandros da sétima narrativa que preenche a primeira parte d' $O$ voo da madrugada, o conto "O embrulho da carne", somos encharcados pela liquidez da Modernidade, de modo que muitos são os paralelos a serem ressaltados a partir de seu contraponto com o Amor líquido, de Bauman.

O conto se passa em uma sessão psicanalítica entre Teresa - mulher de meia idade, separada, fumante, dependente de calmantes, que busca, pela fala, purgar sua ansiedade diante de situações-limites em sua vida - e seu psicanalista, o doutor Elias. No diálogo, há uma construção da linguagem na elaboração psíquica que concretiza experiências passadas no momento presente do relato e, dessa forma, a paciente busca compreender a si mesma e abarcar o mundo líquido em que vive.

Teresa relata ao psicanalista experiências do dia anterior que geraram nela medo, insegurança e conflitos que não parecem fáceis de desembrulhar. Após dirigir sob o efeito de medicamentos, ela bateu o carro em um ônibus, tendo sido auxiliada por um estranho que presta solidariedade, ao oferecer-se para conduzir o carro até seu prédio.

- Ele é o homem que ajudou você quando você bateu o carro?

- Sim, o Ivan. Está certo que só telefonei para ele depois de tomar os remédios, mas eles ainda não deviam estar fazendo efeito. Mas é igual a acender um cigarro, você me entende, uma bengala para a segurança. (Ela sorri, porque tira um cigarro do maço. Mas não o acende). E, sabendo que eu já tinha tomado os remédios e logo ia dormir, eu me sentia mais segura para falar com ele. Ele aceitou na hora o convite para vir jantar no dia seguinte; quer dizer hoje, e agora estou desse jeito e não sei o que fazer. Ele falou que ia trazer o vinho e me perguntou se a gente ia comer carne ou peixe; então eu perguntei o que ele preferiria e ele disse carne, prontamente, de um modo que me pareceu malicioso e me incomodou um pouco, pois afinal, ele era praticamente um estranho, que só viera ao meu apartamento por causa de um acidente. Tentei explicar a ele, embaraçada, que eu lhe devia um agradecimento, e ele disse rindo, "não há de quê, foi um prazer", e só então percebi que minhas palavras podiam estar sendo levadas além da conta. Ou talvez não, sei lá. Mas eu não queria estragar as coisas e disse, rápido e baixinho: "Pra mim também". Eu só queria ser uma mulher normal convidando um homem simpático para jantar, talvez um possível namorado, mas ainda não (Sant'Anna, 2003, p. 57).

Teresa vê, no possível interesse de Ivan, a possibilidade de iniciarem um relacionamento. Isso a deixa insegura, pois os habitantes do mundo fluido sabem que os relacionamentos humanos podem representar bênçãos ou maldições. Sim,

as pessoas vêm e vão, as oportunidades batem à porta e desaparecem novamente logo após serem convidados a entrar, as fortunas aumentam e diminuem, e as coligações tendem a ser flutuantes, frágeis e flexíveis. As pessoas procuram parceiros e buscam "envolver-se em relacionamentos" a fim de escapar à aflição da fragilidade, só para descobrir que ela se torna ainda mais aflitiva e dolorosa do que antes. O que se propunha/ansiava/esperava ser um abrigo (talvez $o$ abrigo) contra a fragilidade revela-se sempre como a sua estufa (Bauman, 2004, p. 41).

Após marcar o jantar com Ivan, Tereza decide ir ao açougue comprar carne - conforme combinado, após o homem expor seu desejo - , apesar de não se sentir à vontade em tal lugar. Ao voltar a casa, ela começa a preparar o estrogonofe com "a mão na carne pra valer" (Sant'Anna, 2003, p. 59). Pensamentos e sentimentos emergem gerando ansiedade e medo. Ela 
começa a imaginar com força libidinosa a figura de Ivan embaralhando-se à de seu ex-marido que a abandonara. Com as pernas trêmulas de agitação, seu olhar é magnetizado por um jornal que embrulhava o plástico com a carne e que apresenta a notícia de uma moça que havia sido violentada e morta brutalmente. Tudo isso desencadeia uma crise ainda maior, dadas as identificações de Teresa com a mulher morta.

$\mathrm{Na}$ tentativa de desvencilhar-se de tal imagem cruel, Teresa decide queimar o jornal em seu quarto, mas o fogo espalha-se pelo quarto e ela fica paralisada. Só volta à normalidade quando a empregada Neuza controla o fogo. A funcionária sugere que Teresa ligue para o seu exmarido, Rodrigo, a fim de relatar a situação em busca de apoio. Na verdade, Teresa precisava e "estava querendo que alguém [a] amparasse, [a] protegesse" (Sant'Anna, 2003, p. 65).

Todavia, ao ser atendida pela mulher atual de Rodrigo, Silvana, que pede que Teresa não incomode o esposo, que "já andava preocupadíssimo com ela e com o filho que vai nascer" (Sant'Anna, 2003, p. 66), mais crises afugentam Teresa. Ela lembra que não pôde concretizar o sonho do marido de gerar filhos, pois não conseguia aceitar a ideia "de ter uma criatura dentro do meu corpo, que depois vai rasgar as minhas carnes para nascer num mundo destes" (Sant'Anna, 2003, p. 66). Após desligar o telefone, Teresa conclui: "Meu Deus, eu não tenho ninguém" (Sant'Anna, 2003, p. 66). A ambivalência da situação e do turbilhão de sentimentos vivenciado por Teresa evoca o pensamento baumaniano:

Essa situação de ter sido abandonado à própria sorte, sem ter com quem contar quando necessário, quem nos console e nos dê a mão, é terrível e assustadora, mas nunca se está mais só e abandonado do que quando se luta para ter a certeza de que agora existe de fato alguém com quem se pode contar, amanhã e depois, para fazer tudo isso se - quando - a roda da fortuna começar a girar em outra direção. É impossível predizer os resultados de nossa luta - e a luta em si cobra o seu preço. E enquanto você espera há muita dor para sentir, lágrimas para verter e sangue para derramar (Bauman, 2004, p. 41).

Certamente, os relacionamentos são representantes ambivalentes que ocupam o cerne das atenções dos líquidos indivíduos que, em sua "agenda existencial" (Bauman, 2004, p. 9), ao buscarem vencer a luta de estar com o outro, sabem que o resultado jamais dependerá de si próprios. Assim são as dificuldades de ajuste enfrentadas por Teresa no cenário líquido: ela, que já fora abandonada e vive sozinha, teme ser rejeitada por Ivan, de modo que pondera:

- Como é que você acha que eu posso encontrar o Ivan, jantar com ele, talvez transar com ele, depois de tudo o que eu senti hoje? Depois de tudo o que aconteceu. O meu quarto está até com cheiro de queimado. [...]

- Vocês precisam necessariamente transar, Teresa?

- Não sei, as coisas podem caminhar para isso. A maneira como Ivan disse "carne" sugeria isso (Sant'Anna, 2003, p. 67).

Teresa pode esperar uma "noite avulsa de sexo" (Bauman, 2004, p. 19), confessa sentir medo da volatilidade da situação e, por conta de sua insegurança, afirma que poderia transar com seu analista naquele momento já que ele a acalmava, mas lembra-se de que se trata de um profissional. Profissional que talvez só lhe estenda a mão pelos honorários que receberá. A insegurança de Teresa parece dificultar sua saída da sessão. Assim, o doutor Elias decide estender a consulta por mais meia hora. Mas é na extensão do tempo que Teresa se dá conta de que não precisa mais dele, ou seja, não pode mais perder tempo na Modernidade líquida:

- Decidiu comer a carne, Teresa?

- Quer saber de uma coisa, Elias? Saindo daqui, vou passar numa loja de colchões e vou comprar um colchão novo e exigir que eles o entreguem ainda hoje, antes do jantar, nem que eu pague um dinheirão. Esse colchão vai pegar fogo hoje à noite, Elias. Porque eu vou comer a carne, vou comer o Ivan, e, se você deixasse, comia você também. - Teresa dá uma gargalhada, deliberadamente louca (Sant'Anna, 2003, p. 70).

Ao final do conto, após tomar sua decisão de ficar com Ivan e comer a carne, Teresa se despede de seu analista e "aproxima, bem mais do que habitualmente, seus lábios dos dele" (Sant'Anna, 2003, p. 70). Representações do desejo se expandem ao final da narrativa como 
"vontade de consumir. Absorver, devorar, ingerir, digerir, aniquilar. [...] um ímpeto de vingar a afronta e evitar a humilhação [...], um impulso de destruição" (Bauman, 2004, p. 23-24).

Assim, o desejo, como catalisador dos relacionamentos fluidos, toma conta da narrativa em que, após o embate da Modernidade "sólida" com a "líquida", modifica-se a identidade da personagem. Ela, finalmente, compreende que "num ambiente fluido, não há como saber se o que nos espera é uma enchente ou uma seca - é melhor estar preparado para as duas coisas" (Bauman, 2005, p. 57).

\section{Representações do desejo e da violência na ficção de Sérgio Sant'Anna}

Considerando que a violência é um dos temas mais caros à ficção brasileira contemporânea, não é surpresa encontrá-la na obra de Sant'Anna como um dos vetores principais de aproximação entre a literatura e a vida social. Embora estejamos longe de atribuir ao autor aquela velha atitude panfletária ou engajamento de caráter menor, que atribui à ficção a tarefa de encaminhar revanchismos ideológicos, não se pode negar que

Em "O embrulho da carne", [...] fica explícito um universo contraditório onde as personagens reais da ficção são exemplos claros de conflitos existenciais que acompanham muitas pessoas que fazem parte do conturbado cotidiano citadino, promovido cada vez mais pelo crescente capitalismo (Gongora, 2006, p. 3).

Para nos mostrar a consciência clara de quem se sabe, como ficcionista, permanentemente envolvido no jogo entre realidade social e criação estética, Sant'Anna constrói sujeitos ficcionais muito representativos do que se pode experimentar como mal-estar da vida contemporânea. Algo como uma cisão entre o indivíduo e os outros, como uma convivência que separa muito mais que reúne e que reduz a experiência social a uma série de incertezas, desejos frustrados e medos. Exemplo claro dessa consciência de artista e de sujeito histórico está no simulacro assumido no discurso do cronista: "Este conto foi imaginado a partir de matérias, sobre o mesmo crime, publicada em O Dia e no Jornal do Brasil de 23.3.1987, um tempo em que ainda havia açougues onde se embrulhava carne com jornais, mas o texto só veio a ser escrito em 1999" (Sant'Anna, 2003, p. 71).

A afirmação acima é um jogo que questiona a própria existência do que tacitamente admitimos como realidade e daquilo que, de maneira tão severa e talvez precipitada, acreditamos ser irreal. Contemporâneo, Sant'Anna dilui fronteiras teóricas e nos convida a retomar a valiosa discussão sobre as relações entre ficção e sociedade. Para deixar claro o recurso poético usado pelo autor, esclarecemos que na fonte indicada por ele (Jornal do Brasil - segunda feira, 23.3.1987) não consta qualquer referência ao crime narrado em "O embrulho da carne".

Considerando o jogo que é proposto ao leitor, o "embrulho" mencionado no título pode retomar a ideia de leitura como desdobramento de possibilidades, coleta de pistas, montagem de evidências que tornem mais compreensíveis as tramas textuais, as armadilhas criadas pelo narrador. Aliás, um dos sentidos do verbo "embrulhar" é "complicar, embaraçar" (Ferreira, 2008, p. 339) e talvez o objeto do verbo caiba ao leitor, a considerar o simulacro criado.

Contudo, ao considerar a carne embrulhada, não podemos deixar de pensar na carne como metáfora do desejo sexual e do discurso que o envolve. Teresa, a protagonista, figura como paciente numa cena da clínica psicanalítica à procura de resolver ou desembrulhar para si mesma o apelo do desejo sexual que a acompanha. Envolto em palavras, em discursos da moral e da religião, o corpo - carne - e o sexo sempre foram condições e experiências segredadas ou vigiadas muito de perto pelas instâncias de controle do indivíduo ou de sua socialização. Todo esse complexo imbroglio entre desejo, discurso e repressão eclode em episódios de violência irracional, como o momento em que Teresa vê a manchete e ateia fogo no jornal atingindo o colchão. Seguindo esse caminho de leitura, admitimos entender a violência como "o uso da força para causar dano físico ou psicológico à outra pessoa, o que, forçosamente, recai na problemática do crime" (Pellegrini, 2004, p. 16).

Na conversa com o psicanalista, Teresa é atormentada pela consciência de que há prazer em devorar e esse é um tormento advindo da civilidade construída com bases na culpa e na repressão do desejo. $\mathrm{O}$ grande mal-estar vivido por ela não está em comer carnes de animais, mas em desejar 
sexualmente a carne de Ivan e depois, de Elias, assimilando-os, destruindo-os para satisfazer-se, porém, sendo por estes também devorada, adquirindo caráter mais brutal, porquanto culpada pelo desejo. Assim, percebemos que o que a corrói é a culpa que acompanha o prazer:

- Não adianta, eu sei aonde você quer chegar. Estou falando de comer de verdade, devorar. Não existe, mas poderia existir. Aliás, até já existiu: os canibais. Mas estou falando é da minha consciência. Não consigo entrar num açougue achando tudo natural. Quer dizer, natural até que é, porque a vida é exatamente assim, uns devorando os outros, só que eu tenho consciência disso o tempo todo e as outras pessoas não. Mas qual a diferença entre nós e os canibais? Nenhuma. Só porque a gente come carne de bicho e eles comiam carne de gente? Mas, pensando bem, os selvagens eram até mais sadios que nós, porque a vida é assim e eles não ficavam se remoendo o tempo todo. Ou os bárbaros, que iam lá, atacavam as outras aldeias, matavam, estupravam. Foi isso o que fizeram com aquela mulher do jornal (Sant'Anna, 2003, p. 58-59).

Para a protagonista, a brutalidade resultante dos nossos desejos reprimidos é mais inadmissível do que o prazer. A pergunta que acompanha sua reflexão nos faz pensar em quanto somos de fato civilizados e em que medida somos selvagens, ou quanto de violência toleramos e produzimos no âmbito da civilização e do discurso moralizante: " - Como é que alguém pode transar com uma mulher assim, e, depois, ainda amarrar ela pelo pescoço num daqueles ferros que ficam no teto dos vagões e puxá-la pelas pernas, até ela morrer? Como é que pode?" (Sant'Anna, 2003, p. 63).

Ao mencionarmos a latência do desejo no corpo da personagem Teresa, não descartamos a inserção desse corpo no conjunto social. Os corpos falam de si e do espaço que ocupam em relação aos demais espaços físicos e sociais, uma vez que carregam as marcas desse espaço na linguagem que exprimem, nos modos de se inserirem no convívio social. Para Regina Dalcastagnè, "ainda que despidas de quaisquer apetrechos, as personagens contemporâneas podem falar de si e do lugar que ocupam no mundo" (2006, p. 72). A fala da protagonista, nos trechos abaixo, revela o lugar social que ela ocupa, mas, ao mesmo tempo, uma humanidade reduzida à última experiência táctil da vida, ou seja, a corporeidade. Sentir dor ou prazer está para além das palavras e das convenções morais, os extremos da condição humana - a violência entre eles - só são vivenciados plenamente pelo corpo, vejamos:

Eu posso ser uma burguesinha fresca que faz análise, mas, de repente, aquela moça enforcada era eu, entende? E muito mais do que você imagina. Porque eu era ela até fisicamente, pois minha mão estava suja da tinta do jornal e engordurada da carne. $\mathrm{Na}$ pressa de sair da cozinha, nem lavei as mãos e, para mim, eu estava engordurada era da carne da moça. Ao mesmo tempo, era eu quem balançava, enforcada, na escuridão da noite, num vagão de trem abandonado. E não havia ninguém para vir em meu socorro; não havia ninguém comigo (Sant'Anna, 2003, p. 64).

- Eu já disse, era como se eu fosse mesmo obrigada. Já tendo visto a mulher, eu não podia ignorá-la, fingir que tudo ia no melhor dos mundos. Eu ali na minha cobertura (ela diz isso com autodesprezo), preparando um estrogonofe, e a mulher dependurada na cabine do trem-fantasma, como estava escrito no jornal (Sant'Anna, 2003, p. 61).

Essa opção pelo corpo como depositário do desejo reprimido está bastante vinculada ao espaço urbano como o mais representativo dos mundos moderno e contemporâneo. Se admitirmos que "a ficção brasileira da contemporaneidade tem suas raízes no solo urbano" (Cury, 2007, p. 9), entenderemos também a cidade como espaço potencializado da ficção de Sant'Anna. Teresa está inserida na instabilidade das relações humanas e no caráter descartável e instantâneo de tudo que o corpo consegue aferir ao seu redor. Ela mesma, Teresa, descartada pelo marido e bem próxima de um encontro em que poderia descartar e/ou ser descartada. Como a moça que depois de violentada e enforcada virou apenas notícia que embrulha a carne, a própria Teresa anda às voltas com a sensação física da morte, da carne se desfazendo. Talvez daí venha seu desinteresse pela ideia de ser mãe, de sentir suas entranhas rasgando para dar vida a outro. 
Curioso é o fato de haver um paralelo entre os corpos violentados da protagonista e da moça na manchete do jornal. Se Teresa representa a violência psicológica sofrida por todos os que estamos sobre a tutela da civilização, é sobre o corpo que essa violência eclode com insanidade. Atento aos caminhos da contemporaneidade, Sant'Anna não deixa de discutir os efeitos da imagem sobre a sociedade. Se a palavra escrita moldou o homem moderno, a imagem entra pelos olhos dando a conhecer sensorialmente a realidade, o corpo mutilado do outro, e provocando um extremo táctil de reconhecimento de si no quadro visual. Sim, tal ficção consegue "efeitos sensuais e afetivos parecidos ou idênticos aos encontros extremos e chocantes com a realidade em que o próprio sujeito é colocado em questão" (Schøllhammer, 2002, p. 82).

Após o percurso pelas sendas do desejo, da melancolia, do medo e da violência do conto "O embrulho da carne", passamos agora à análise estético-recepcional jaussiana.

\section{A premissa da Modernidade sob a estética da recepção em Sérgio Sant’Anna}

Enviesando para a discussão do conto "O embrulho da carne" de Sant'Anna, sob o olhar fundamentado na estética da recepção de Hans Robert Jauß (1921-1997), com apoio em uma análise crítica calcada na terceira tese da obra $A$ história da literatura como provocação à teoria literária (1969/1994) - que apresenta o diálogo entre Theodor Adorno (1903-1969) em Teoria estética (1988) e Jauß -, busca-se apresentar como, no conto em questão, é possível fazer uma crítica que abarca a denúncia social, revelando-a, portanto, como negatividade, sem resvalar em desvalorização da experiência estética, tornando a obra literária "arte culinária". Sobretudo, propõe-se destacar a premissa de leitura marcada por um horizonte de expectativa da Modernidade.

O comentário de Jauß sobre Adorno se situa em um ponto específico de discussão em que o teórico alemão fundador da estética da recepção discorda em parte com o filósofo da Escola de Frankfurt. Iniciando pelo tópico de concordância entre os autores, Jauß mostra como o conceito adorniano de "arte culinária" revela uma experiência sem caráter estético, pois atender ao gosto dominante para suprir uma cultura de massa, explorar o belo usual seguindo tendências e padrões de mídia de época, tornar palatável o objeto artístico para não se correr o risco de desagradar, solucionar problemas corriqueiros como o de indivíduos da elite que necessitam de status, entre outros, são elementos que configuram um objeto voltado para indústria cultural, como propõe Adorno, em Teoria estética.

Jauß mostra que, para o filósofo da Escola de Frankfurt, o valor estético da arte se daria por um par dialético entre arte e sociedade ou realidade empírica versus crítica à sociedade, sendo esta uma denúncia da primeira. Dessa maneira, seria inadmissível o prazer na experiência estética, pois, para Adorno, o deleite diante do objeto artístico seria resultado da "arte culinária" correspondendo aos caracteres dessa como foi dito anteriormente, por isso, expõe que:

Sem dúvida, não é por isso que as obras de arte positivas e afirmativas - a quase totalidade das obras tradicionais - se devem varrer ou defender apressadamente mediante o argumento demasiado abstrato de que também elas são críticas e negativas, devido à sua posição abrupta à empiria. A crítica filosófica do nominalismo irrefletido proíbe que se reclame sem mais a vida da negatividade progressista - negação do sentido objetivamente constrangente - como senda do progresso da arte (Adorno, 1988, p. 182).

Para Adorno, a identificação na arte estabelece um vínculo com o mercado de consumo em que existe uma indústria cultural voltada para interesses do comércio, logo, o objeto artístico que não pode negar a realidade social e causar prazer não se constitui enquanto arte. Como negatividade, o conto de Sant'Anna denuncia as relações interpessoais abaladas na era de transição da Modernidade pesada (grandes máquinas e capital físico) para a Modernidade leve marcada pelos softwares e capital financeiro (virtual). A intriga literária dialeticamente se opõe aos interesses de uma classe dominante que comanda as tecnologias voltadas para o mercado de consumo e provoca consequências no comportamento humano natural, que buscaria a interação entre indivíduos sociais. Desse modo, Teresa apresenta dificuldade em entrar em local 
público e, ao se colocar em meio a outras pessoas, comprar carne, sem fazer referência à violência cotidiana, entra em crise.

A capacidade de reconhecer como naturais as relações entre os seres humanos é detectada pela personagem, no entanto, ela não consegue agir de forma natural, pois sua conduta é marcada por fatores da Modernidade que afetam sua vida, colocando-a em uma posição de conflito entre o reconhecimento da lei da vida - em que "uns devoram os outros" como um ato natural - e a consciência deste ato. A negação do comportamento humano regido por elementos da Modernidade leve apresenta-se ainda quando Teresa utiliza o telefone como forma de se relacionar com Ivan, mas quando é necessário o contato pessoal com outras pessoas, isso se torna algo complexo. Nesse ponto, concebe-se uma oposição da arte em relação à realidade empírica contemporânea, na qual o leitor rejeita essa realidade representada e não se deleita com ela, sobretudo por se ver em meio a um contexto de dominação de uma classe elitizada.

O processo contínuo de recepção proporcionado pela historicidade própria da obra literária pode gerar, em experiências futuras, seja pelo horizonte do texto, do leitor ou até mesmo na fusão destes, a identificação, o que torna a negatividade positividade. Assim, a arte mostra seu caráter de comunicação. $\mathrm{O}$ que Jauß concebe nesse momento não é uma oposição radical em relação à concepção de Adorno nem mesmo uma forma de aceitar a arte culinária; pelo contrário, Jauß se mantém radicalmente contra a arte voltada para a indústria cultural, concordando, nesse aspecto, com o filósofo de Frankfurt. Para Jauß, a experiência estética é passível de prazer, e o leitor pode se identificar e se deleitar, não admitindo o objeto artístico como negação da sociedade, concordando, por exemplo, com a identificação com o opressor ou com aqueles que impõem as normas na sociedade (elite), por isso, expõe que:

Se, inversamente, trata-se de avaliar o caráter artístico de uma obra pela distância estética que a opõe à expectativa de seu público inicial, segue-se daí que tal distância - experimentada de início com prazer ou estranhamento, na qualidade de uma nova forma de percepção - poderá desaparecer para leitores posteriores, quando a negatividade original da obra houver se transformado em obviedade e, daí em diante, adentrado ela própria, na qualidade de uma expectativa familiar, o horizonte da experiência estética futura (Jauß, 1994, p. 32).

Pensando em uma forma de identificação que não se vincula ao entretenimento, ao belo usual, ao mercado de consumo etc., "o embrulho da carne" poderia ser lido sob uma perspectiva de horizonte de expectativa de prazer, na qual o leitor se deleitasse com o desespero dos indivíduos que temem pela violência e que o Deus cristão da bonança, a partir da perspectiva da personagem, se faz ausente diante das atrocidades. Assim, o deleite seria possível também para os que clamam pelo poder divino e não são atendidos porque Deus se mostra impotente. É óbvio que não se deve confundir este prazer estético com o ressentimento cristão, calcado em torcer pelo sofrimento dos que não se curvam diante de Deus, para, dessa forma, legitimar a força desse ente divino. Mas é concebível que a literatura possui, segundo Jauß, uma configuração que vai além de uma arte da representação, pois ela "se manifesta historicamente, a cada vez que a obra de arte contribui para a emergência de novas tendências ou quando os modelos representados introduzem profundas transformações na conduta privada e social" (Miranda, 2007, p. 49).

Portanto, a configuração da arte enquanto tal é capaz de gerar prazer na experiência estética e contribuir para que o leitor se abra para compreender as opressões impostas pela práxis social. Nesse caso, o leitor poderia fruir um prazer estético pela constatação, através da arte literária, da ineficácia do discurso cristão na sociedade, o qual se revela incapaz de frear a violência da Modernidade, como demonstra Sant'Anna:

- Já pensou no terror que ela deve ter sentido ao ser estuprada e morta? Ela deve ter pedido: "pelo amor de Deus, não me matem". Mas que Deus é esse, que deixa acontecer uma coisa dessas? Será que não é melhor morrer do que viver num mundo assim? (Sant'Anna, 2003, p. 63).

O diálogo travado a partir da relação entre Jauß e Adorno e sua aplicação ao conto "O embrulho da carne", certamente, permitiu-nos constatar que o teórico alemão da estética da 
recepção não assume uma postura contra o filósofo da Escola de Frankfurt, mas revelou-se, sobretudo a partir da narrativa contemporânea de Sant'Anna, que a experiência estética não se caracteriza somente pelo caráter dialético da negatividade.

\section{Feito um pacote flácido?}

Como vimos, o conceito de liquidez trabalhado pelo sociólogo Zygmunt Bauman perpassa o texto literário "O embrulho da carne", de Sant'Anna. Além da temática dos relacionamentos líquidos, observamos vestígios da violência, a dupla identidade, o dilaceramento da personagem, bem como se tornou possível um profícuo diálogo com críticos representativos da produção literária contemporânea, tais como Maria Zilda Cury, Tânia Pellegrini, Karl Erik Schøllhamer e Regina Dalcastagnè. Tais críticos permitem situar a discussão acerca das questões abordadas na literatura brasileira contemporânea e como elas emergem no texto de Sant'Anna.

Todos os elementos da Modernidade apontados pela crítica podem ser retomados pela estética da recepção, uma vez que a experiência dialógica com "O embrulho da carne" permite traçar um horizonte de expectativa que pode ser recebido como negatividade, em que o leitor não goza da experiência estética, ou como identificação, ao proporcionar prazer sem fruição de uma "arte culinária". O ganho perceptível, quando aplicada a teoria jaussiana ao texto de Sant'Anna, é conceber, além de aspectos pertencentes à obra, outros que dizem respeito ao leitor, como prazer, rejeição, identificação - os quais não são mencionados por outras concepções que se voltam unicamente para o texto literário, colocando o receptor em um lugar secundário ou apagado.

$\mathrm{Na}$ fluidez de nossa leitura, propomos, portanto, que são os leitores os principais protagonistas deste ambivalente Voo da madrugada, os quais, ao rasgar os embrulhos do texto eleito, podem vislumbrar claramente aspectos da Modernidade líquida, sentindo nas próprias carnes circunscreverem-se as narrativas de desejo, medo e violência propostas por Sant'Anna. Alcançamos pela literatura magnetizante deste escritor contemporâneo uma melhor compreensão das nuances de nossa líquida sociedade brasileira nesse coletivo voo solitário que nos carrega como embrulhos.

\section{Referências}

ADORNO W. Theodor (1988). Teoria estética. Tradução de Artur Morão. São Paulo: Martins Fontes.

BAUMAN, Zygmunt (2001). Modernidade líquida. Tradução de Plínio Dentizien. Rio de Janeiro: Jorge Zahar.

BAUMAN, Zygmunt (2004). Amor líquido. Tradução de Carlos Alberto Medeiros. Rio de Janeiro: Jorge Zahar.

BAUMAN, Zygmunt (2005). Identidade. Tradução de Carlos Alberto Medeiros. Rio de Janeiro: Jorge Zahar.

CURY, Maria Zilda Ferreira (2007). Novas geografias narrativa. Letras de Hoje, Porto Alegre, v. 42, n. 4, p. 717 , dez.

DALCASTAGNÈ, Regina (2005). Violência, marginalidade e espaço na narrativa brasileira contemporânea. Diálogos latino-americanos, Aarhus, v. 11, p. 72-82.

FERREIRA, Aurélio Buarque de Holanda (2008). Miniaurélio: o minidicionário da língua portuguesa. 7. ed. Curitiba: Positivo.

GONGORA, Anderson Possani (2006). Ficção e violência: as narrativas de Sérgio Sant'Anna e leituras sufocantes. In: CONGRESSO INTERNACIONAL ABRALIC, 10.,. Anais [...] Rio de Janeiro: Abralic. p. 1-8.

JAUSS, Hans Robert (1969/1994). A história da literatura como provocação à teoria literária. Tradução de Sérgio Tellaroli. São Paulo: Ática. 
MIRANDA, Mariana Lage, (2007), Objeto ambíguo: arte e estética na experiência contemporânea, segundo H. R. Jauss. Dissertação (Mestrado em Filosofia) - Universidade Federal de Minas Gerais, Belo Horizonte.

PALLARES-BURKE, Maria Lúcia Garcia (2004). Entrevista com Zigmunt Bauman. Tempo social, São Paulo, v. 16, n. 1, p. 301-325.

PELLEGRINI, Tânia (2004). No fio da navalha: literatura e violência no Brasil de hoje. Estudos de Literatura Brasileira Contemporânea, Brasília, n. 24, p. 15-34, jul./dez.

SANT'ANNA, Sérgio (2003). O voo da madrugada. São Paulo: Companhia das Letras.

SANT'ANNA, Sérgio (2012). Sérgio Sant'Anna, o autor imprevisível. [Entrevista concedida a] Guilherme Pavarin. Revista Época, 19 out. Disponível em: http://revistaepoca.globo.com/cultura/noticia/2012/10/sergiosantanna-o-autor-imprevisivel.html. Acesso em: $1^{\mathrm{o}}$ jan. 2019.

SCHØLLHAMER, Karl Erik (2009). O realismo de novo. In: SCHØLLHAMER, Karl Erik Ficção brasileira contemporânea. Rio de Janeiro: Civilização Brasileira. p. 53-104.

\section{Nota}

Sendo este artigo fruto de discussões e seminários realizados no âmbito da disciplina Literatura Brasileira Contemporânea, ministrada pelo prof. dr. Sílvio Augusto de Oliveira Holanda (in memoriam), no Doutorado em Teoria Literária do Programa de Pós-Graduação em Letras (PPGL) da Universidade Federal do Pará (UFPA), em 2016, os autores expressam agradecimento especial à memória do mestre que provocou e iluminou a elaboração deste texto. 